TEME, г. XLIII, бр. 3, јул - септембар 2019, стр. 885-899

Прегледни рад

Примљено: 27. 2. 2019.

https://doi.org/10.22190/TEME190227053P

Ревидирана верзија: 30. 5. 2019.

Одобрено за штампу: 20. 10. 2019.

\title{
ПОСТМАТЕРИЈАЛИЗАМ У СРБИЈИ
}

\author{
Нина Павловић \\ Универзитет у Нишу, Филозофски факултет, \\ Департман за социологију, Ниш, Србија \\ "nina.pavlovic@filfak.ni.ac.rs
}

\begin{abstract}
Апстракт
Теорија модернизације Роналда Инглхарта пружа модел промена вредности на глобалном плану, уз афирмацију специфичних националних путања промена. У раду је размотрен значај индекса постматеријализма, као кључног елемента димензије самоекспресије. Приказана је дистрибуција (пост)материјалистичких вредности у Србији на основу података из Европске студије вредности и Светске студије вредности из 2001, 2005. и 2008. године. Подаци указују на постојање стабилне структуре у којој преовладавају мешовити и материјалистички тип. Применом регресионе анализе на податке за 2008. годину испитан је утицај социодемографских фактора на постматеријализам. Резултати указују на значајан утицај старости, нивоа образовања и величине града, док утицај висине прихода није статистички значајан. Добијени резултати подржавају Инглхартову теорију вредности, али не искључују ефекат животног циклуса.
\end{abstract}

Кључне речи: индекс постматеријализма, теорија модернизације, социодемографски модел, Европска студија вредности, Србија.

\section{POSTMATERIALISM IN SERBIA}

\begin{abstract}
Ronald Inglhart's modernization theory provides a model of global value change, with affirmation of specific national paths of change. The paper considered the importance of the index of postmaterialism as a key element of the self-expression dimension. The distribution of (post)materialistic values in Serbia is presented based on data from the European Values Study and World Values Study from 2001, 2005 and 2008. The data indicate the presence of a stable structure in which the mixed and materialistic type predominates.The influence of sociodemographic factors on postmaterialism was examined by applying the regression analysis to the data from 2008. The results indicate a significant influence of the age, level of education and size of the city, while the impact of the amount of income is not statistically significant. The obtained results support Inglhart's theory of values, but do not exclude the effect of the life cycle.
\end{abstract}

Key words: postmaterialism index, modernization theory, sociodemographic model, European value study, Serbia. 
Теорија модернизације истиче условљеност културних промена и друштвеног прогреса економским развојем. Ово гледиште има корене у просветитељском концепту доминације разума и технологије над природом. Нелинеарност и неуједначеност нивоа развоја друштава и нарушавање ауторитета науке у пројекту постмодерности указују на потребу прилагођавања ове теорије; једна од очигледних карактеристика теорије модернизације коју је неопходно модификовати је, како Инглхарт (Inglehart \& Welzel, 2005, стр. 18-19) истиче, претходно заступљено уверење да ће различите традиције Истока и Запада нестати. Роналд Инглхарт у оквиру сопствене теорије модернизације полази од промена у вредносним оријентацијама, које су изазване индустријализацијом друштва и испољавају се доминантно дуж две димензије: а) димензија традиционалних / секуларно-рационалних вредности и б) димензија вредности преживљавања/самоекспресије (Inglehart \& Baker, 2000). Аутор дефинише модернизацију као процес који изнад свега оснажује економске и политичке потенцијале друштва; економске кроз индустријализацију, а политичке кроз бирократизацију (Inglehart, 1997). Циљ рада је анализа заступљености материјалистичких и постматеријалистичких вредности у Србији према подацима Европске студије вредности и Светске студије вредности из 2001, 2005. и 2008. године, као и тестирање хипотезе о утицају социодемографских фактора на усвајање (пост)материјалистичких вредности, на подацима за 2008. годину на основу поставки Инглхартове теорије и на основу алтернативних хипотеза о ефекту прихода, величине насеља и нивоа образовања у тренутку прикупљања података.

\section{СТРУКТУРА ВРЕДНОСТИ У ИНГЛХАРТОВОМ МОДЕЛУ}

Вредносне оријентације постављају „пожељне и непожељне” циљеве, те представљају значајне мотиваторе (и предикторе) људског понашања (Inglehart \& Welzel, 2005, стр. 23). Инглхарт анализира промене вредносних оријентација у идеално-типским конструктима прединдустријских, традиционалних и индустријских, модерних друштава, истичући да је реч о генерализацијама у оквиру којих су замагљене очигледно присутне разлике између конкретних друштава и апстраховане битне карактеристике које су присутне у свим или скоро свим друштвима у оквиру једног типа (Inglehart \& Baker, 2000). За традиционална друштва карактеристичан је велики значај религије, поштовање традиционалних ауторитета, идеализовање великих породица и сопствене нације, уз наглашену политичку пасивност и конформизам; у модерном друштву заступљен је супротни пол ове димензије, секуларно-рационални насупрот традиционал- 
ном. У прединдустријском друштву бројност и заштита унутар породице кључне су за опстанак, одакле следи њена идеализација, као и неоправдавање абортуса, еутаназије и самоубиства. Како су ресурси ограничени у традиционалном друштву, присутна је несигурност и низак ниво квалитета живота; због чега је примарни фокус на обезбеђењу сигурности и других материјалних циљева, као и дистанца према странцима, инсистирање на традиционалним родним улогама и ауторитарности. Ове вредности обухваћене су димензијом вредности преживљавања/самоекспресије, а њена централна компонента су (пост)материјалистичке вредности. Појединци теже традиционалним улогама и нормама да би повећали ниво сигурности максимизирајући предвидљивост; тако се у овим друштвима негирају једнакост и права жена, припадника ЛГБТ популације и странаца (Inglehart \& Baker, 2000).

Промене на димензијама вредности Инглхарт објашњава путем хипотеза оскудице и социјализације: хипотеза оскудице подразумева да приоритети појединца зависе од друштвеног контекста, у коме се највећа вредност придаје ресурсима који су доступни у ограниченим количинама (Inglehart, 2000). Владајући приоритети и њихова промена могу се објаснити Масловљевом теоријом о хијерархији потреба; на врху су потребе које осигуравају опстанак човека, храна и безбедност; након којих следе потребе самоостварења: потребе за љубављу, припадањем и поштовањем (Inglehart, 1977). Дакле, са економским развојем друштва и побољшањем материјалних услова, задовољене су вредности које су на врху хијерархије потреба, па приоритет добијају вредности које су на нижем нивоу. Хипотеза социјализације конкретније објашњава начин одвијања промена вредности. Ова промена одвија се путем смене генерација (кохорти), при чему највећи утицај на то да ли ће до промене вредности доћи има ниво егзистенцијалне сигурности у раним, формативним годинама живота појединаца - поред материјалних услова, битни фактори егзистенцијалне сигурности могу бити рат, болест и криминал (Inglehart \& Baker, 2000). Претпостављено је да се вредности усвојене у раним годинама тешко мењају током живота ако у друштву не дође до значајних друштвених потреса. Дакле, појединци који усвоје претежно материјалистичке вредности током формативних година проживљених у условима материјалне несигурности - тешко их мењају током каснијих година живота без обзира на касније евентуално поправљање материјалног стања. Постављену теорију аутор поткрепљује анализом емпиријских података Светске студије вредности и Европске студије вредности које су спроведене у шест таласа од 1981. године, уз стално повећање броја обухваћених држава.

У оквиру ревидиране теорије модернизације, Инглхарт истиче дивергенцију исхода индустријализације у различитим друштвима, 
који настаје као резултат „зависности од путање” развоја друштва његовог културног и религијског наслеђа (Inglehart \& Baker, 2000; Inglehart \& Welzel, 2005); теорија модернизације је пробабилистичка, не детерминистичка, она пружа могућност предвиђања само општег смера кретања промена. Аутор препознаје тренд ширења постмодерних вредности у развијеним земљама (док се у земљама у развоју још увек одвија процес преласка у модерно друштво); масовна продукција и бирократија које су омогућиле модерно друштво такође су и умањиле аутономију појединца, те су непожељне у постмодерном свету (Inglehart, 2000). У постмодерном друштву уочава се и крајњи домет утицаја економских фактора на постизање личног благостања. Постмодернизација представља „промену у стратегијама опстанка”, које се преусмеравају на увећавање квалитета живота, пошто опстанак више није доведен у питање (Inglehart, 1997, стр. 456). Постмодерно друштво постаје осетљиво на ризик; док је током модернизације нагласак на дистрибуцији ресурса, у постмодерности је кључна дистрибуција нуклеарних, еколошких и генетичких ризика (Inglehart \& Baker, 2000; Inglehart \& Welzel, 2005).

\section{ПОСТМАТЕРИЈАЛИЗАМ}

Кључни елемент димензије вредности преживљавања/самоекспресије представљају постматеријалистичке вредности. Постматеријализам је операционализован кроз избор два преферентна државна циља од четири понуђена: одржавање реда, сузбијање раста цена, повећање учешћа грађана у доношењу одлука и заштита слободе говора. Комбинација избора прва два циља представља материјалистичку оријентацију, последња два циља постматеријалистичку, а све остале могућности карактеришу мешовити тип. Поред овог индекса, формиран је и шири конструкт од 12 ајтема, али је број ставки редукован да би се избегло искључивање земаља из анализе, у случају недостајућих података на једној од варијабли. Постматеријалистичке вредности нису новитет у квалитативном смислу; најзначајнија је квантитативна промена, у заступљености ових вредности у млађим старосним групама у модерним друштвима (Inglehart, 1977). Алтернативно објашњење овог тренда је ефекат животног циклуса, али би у случају оправданости овог аргумента наведени тренд био присутан у свим друштвима, независно од нивоа развоја (Inglehart, 1977).

Ако се претпостави да овако формиран индекс изражава вредносну оријентацију, очекиван је значајан ефекат индекса у предикцији повезаних специфичних ставова (Inglehart, 1977, стр. 30). Инглхарт (1977, Abramson \& Inglehart, 1992) потврђује повезаност индекса са већим бројем ставова; када је реч о политичким питањима, постматеријалисти чешће подржавају студентске демонстрације, оцењују као зна- 
чајнији циљ помоћ неразвијеним земљама, док материјалисти више вреднују национални престиж. Поред друштвених циљева, постматеријалистичке вредности одражавају се и на личне ставове; тако су материјалистима најважније карактеристике радног места, сигурност и висина плате, а постматеријалистима осећај постигнућа и радни услови. Усмереност материјалиста на задовољење основних људских потреба доводи до недостатка интересовања за проблеме који их не погађају директно, отворености за нове идеје и до заступљености парохијалног менталитета насупрот космополитизму постматеријалиста, те материјалисти највише вреднују припадност свом насељу и региону, а постматеријалисти припадност свету и Европи (Inglehart, 1977). Критика указује на одступајуће резултате и дефинише индекс као мерило система ставова, а не вредности (Trump, 1991; Braithwaite, Makkai \& Pittelekow, 1996; Davis, Dowley \& Silver, 1999, Davis \& Davenport, 1999; Davis, 2000). Једна од критика односи се на вишедимензионалност овог индекса (Bean \& Papadakis, 1994; Brooks \& Manza, 1994; Marks, 1997; Giacalone \& Jurkiewicz, 2004). У складу са Масловљевом теоријом хијерархије потреба, постматеријалистичке вредности могу се јавити тек након задовољења материјалистичких потреба, те постматеријалистичке вредности не подразумевају нужно и негацију материјалистичких вредности. Упркос критикама, у оквиру ревидиране теорије модернизације није модификована димензионалност индекса; са једне стране, постоје емпиријске потврде и једнодимензионалне и вишедимензионалне структуре, а са друге стране, Инглхарт истиче да је избор индикатора за дистинкцију димензија вредности изабран у циљу обухвата различитих сфера са циљем мерења ширих димензија кроскултурних варијација (Inglehart \& Baker, 2000). Дакле, индекс постматеријализма, као и остали индикатори вредности, конструисан је као робусна и једноставна мера у оквиру комплексније структуре, конструкт унутар конструкта, што не искључује накнадна детаљна разматрања ове вредности и димензионалности њене структуре.

Хипотеза социјализације такође је оспоравана, уз истицање значаја тренутне материјалне ситуације, и нивоа образовања за формирање вредности (Dutch \& Taylor, 1993; De Graaf\&Evans,1996): аутори истичу да је материјални статус од великог значаја за усвајање (пост)материјалистичких вредности, али када је реч о материјалном стању у тренутку спровођења истраживања, а не током формативних година. Према Инглхарту, образовање је један од најзначајнијих фактора одређивања вредности, али рефлектује више чинилаца: социокултурни статус породице, ниво когнитивног развоја, неформалне комуникацијске обрасце и директну индоктринацију (Inglehart, 1977). Дакле, може се закључити да је евидентан значај образовања афирмисан и у оквиру теорије модернизације и у оквиру алтернативних гледишта. 
Међутим, питање утицаја материјалне сигурности током формативних година остаје отворено, са једне стране, због постојања супротстављених резултата емпиријских истраживања, а са друге стране и због недостатка алтернативне теорије.

Иако емпиријске анализе указују на одређене слабости постављене теорије, овај концепт остаје непољуљан у позицији доминантног објашњења промена вредности, јер се наведене критике темеље на емпиријским резултатима, а не на преиспитивању теоријских поставки. Стога овакав индуктивистички приступ теорији промена вредности и поред вишегодишњих критика не резултира пружањем алтернативне (подједнако значајне и утемељене) теорије. Разлике у резултатима емпиријских анализа на националном нивоу су једним делом образложене аргументацијом ревидиране теорије модернизације - различитост путања развоја земаља доводи и до различитих позиција постматеријализма у систему вредности, те и до одређеног нивоа нестабилности ове димензије. Ова интерпретација објашњава већу стабилност Инглхартовог модела у анализи на основу средњих вредности већег броја земаља него у случају посматрања појединачних земаља. Док Инглхартова теорија упућује на општи смер кретања савременог глобалног друштва, не искључује постојање националних специфичности; експликативну моћ мапа вредности на макро нивоу свакако треба допунити дубљим разумевањем у културном и историјском контексту на мезо нивоу.

Битно је указати на потенцијални ефекат вредности постматеријализма на политички систем; на основу анализе података из 73 земље, утврђена је повезаност вредности самоизражавања са успостављањем демократских институција, са коефицијентом корелације од 0,9 (Inglehart, y: Esmer \& Pettersson, 2007, стр. 27). Аутор сматра да је смер ове везе такав да промене у вредностима претходе успостављању ефективне демократије; он одбацује супротно тумачење, да се вредности самоизражавања развијају у демократским друштвима, указујући на изостанак ширења ових вредности у постсоцијалистичким земљама (Inglehart, 2000). Треба приметити да у оквиру ове аргументације Инглхарт занемарује разликовање формалне и ефективне демократије; може се тврдити да је транзиција постсоцијалистичких земаља ка суштински демократском систему процес који још увек траје, с обзиром на друштвена превирања и културно-историјске обрасце који се у великој мери разликују од темеља на којима је успостављена демократија западних земаља. Узимајући у обзир обе могуће интерпретације ове повезаности, свакако је релевантан значај постматеријалистичких вредности као чиниоца димензије вредности самоекспресије у евалуацији тренутног стања демократије у друштву и потенцијала њеног опстанка. 
На основу анализе података Светске студије вредности из 2001. године, Павловић (2006) упоређује вредности у Србији са осталим европским земљама, закључујући да је једна од ретких држава у којима материјалистичка оријентација преовладава чак и у односу на мешовити тип, који је најбројнији у већини земаља. Поред тога, грађане Србије карактерише низак ниво квалитета живота, низак ниво поверења у грађанске институције и висок ниво поверења у традиционалне институције - занимљиво је да када се посматра комбинација последње две карактеристике, ниједна од земаља нема ниже поверење у грађанске институције и више поверење у традиционалне (Павловић, 2006). У истраживању из 2013. године, Д. Гавриловић (2013) представља модел заступљених типова вредности у Србији, који упућује на присуство две јасно раздвојене вредносне оријентације, традиционалне и секуларно-рационалне које конзистентно раздвајају групе ставова у вредносном простору Србије, на тај начин да присуство става са једног од полова димензије повлачи са собом скуп сродних ставова. Уз то, као доминантне карактеристике традиционалне димензије у Србији издвајају се поштовање ауторитета и религиозност (Гавриловић, 2013).

\section{МЕТОД}

У овом раду биће испитана заступљеност материјалистичких и постматеријалистичких вредности у Србији на подацима Светске студије вредности $(2001,2005)$ и Европске студије вредности (2008), а затим испитан социодемографски модел уз поређење са резултатима претходног истраживања из 2007. године (Pavlović, 2009). Циљ рада је: а) анализа заступљености материјалиста и постматеријалиста у различитим старосним групама 2001, 2005. и 2008. године; б) тестирање хипотезе о утицају социодемографских фактора на усвајање (пост)материјалистичких вредности, на подацима из 2008. године - на основу поставки Инглхартове теорије може се очекивати значајан ефекат старости (с обзиром на то да се претпоставља да различите генерације усвајају различите (пост)материјалистичке вредности кроз различита искуства у формативним годинама), а из аргументације наведених критика следи значајан ефекат прихода у тренутку прикупљања истраживања, величине насеља и нивоа образовања. Анализирана је дистрибуција материјалистичких и постматеријалистичких вредности у Србији према подацима Европске студије вредности и Светске студије вредности из 2001, 2005. и 2008. године. На податке из 2008. године примењена је регресиона анализа за испитивање значајних социодемографских фактора који утичу на дистрибуцију (пост)материјалистичких вредности, по узору на Павловићево истраживање у ком се утицај социодемографских 
фактора испитује на подацима из Србије, прикупљеним током 2007. године на узорку од 1410 испитаника, тестирајући хипотезу социјализације и алтернативне претпоставке критике (Pavlović, 2009). Moдел укључује факторе обухваћене Инглхартовом теоријом и факторе које критика наглашава (приход, величина насеља и образовање); међутим, треба напоменути да је позиција величине насеља и образовања делимично образложена и у оквиру ревидиране теорије модернизације. Испитивање социодемографског модела ограничено је на најновије доступне податке, из 2008. године. Испитивана популација обухвата пунолетно становништво, за коју је процењено на основу пописа становништва из 2002. године да је у тренутку прикупљања података у земљи присутно 6.063.208 припадника испитиване популације. Спроведен је троетапни стратификовани узорак, који обухвата 1512 испитаника. Узорак чини 46,4\% мушкараца и 53,6\% жена. Старост испитаника креће се од 18 до 89 година, а просечна старост је 45,97 година. Спроведена је регресиона анализа са индексом постматеријализма ${ }^{1}$, као зависном варијаблом, и следећим независним варијаблама: приход (категорије: низак, средњи, висок), старост, величина насеља (категорије: до 5.000, 5.000-20,000, 20.000$100.000,100.000-500.000$, више од 500.000) и ниво образовања (осам категорија - од непотпуног основног до универзитетског, високог образовања).

\section{РЕЗУЛТАТИ}

Претходна истраживања показују да су у Србији најзаступљенији материјалистички и мешовити тип; у истраживању из 1990. године на популацији узраста од 15 до 27 година, најзаступљенији је мешовити тип (42\%), док се материјалистичка оријентација јавља код $32 \%$ испитаника, а нематеријалистичка у $26 \%$ случајева (Пантић, 1990 , стр. 50). Резултати истраживања из 2007. године показују сличну дистрибуцију од по $47 \%$ материјалистичког типа, $47 \%$ мешовитог типа и 6\% постматеријалистичког (Pavlović, 2009: 182). У Табели 1 приказана је дистрибуција материјалистичких и постматеријалистичких вредности у Србији према подацима Европске студије вредности и Светске студије вредности; материјалистичке вредности су најзаступљеније према подацима из 2001. и 2005. године, док је у скоријем истраживању најзаступљенији мешовити тип. Дистрибуција је у складу са резултатима претходних истраживања, те упућује на континуирано превладавање мешовитог типа и материјалистичког типа.

\footnotetext{
${ }^{1}$ Факторска анализа потврдила је једнодимензионалност индекса.
} 
Табела 1. Дистрибуиија материјалистичког и постматеријалистичког типа

\begin{tabular}{lrrr}
\hline & 2001. & 2005. & 2008. \\
\hline Материјалистички тип & $48,8 \%$ & $51,2 \%$ & $43,2 \%$ \\
Мешовити тип & 573 & 476 & 621 \\
& $45,1 \%$ & $44,6 \%$ & $51 \%$ \\
Постматеријалистички тип & 529 & 415 & 734 \\
& $6,1 \%$ & $4,2 \%$ & $5,8 \%$ \\
& 71 & 39 & 84 \\
\hline
\end{tabular}

Регресиони модел је значајан $(\mathrm{F}=10,960, \mathrm{p}=0,000)$ и објашњава $3,4 \%$ варијансе $\left(\mathrm{R}^{2}=0,037\right.$; кориговани $\left.\mathrm{R}^{2}=0,034\right)$. Низак допринос социодемографских фактора објашњењу постматеријалистичких вредности је у складу са претходним истраживањима, мада је проценат објашњене варијансе нижи од очекиваног: социодемографски модел објашњава 9\% варијансе у Павловићевом истраживању. Стандардизовани бета коефицијенти приказани су у Табели 2. Најснажнији је утицај величине насеља, док је утицај старости и нивоа образовања скоро једнаког интензитета, а утицај прихода није статистички значајан ${ }^{2}$.

Табела 2. Коефищијенти регресионог модела (2008)

\begin{tabular}{lcc}
\hline & $\beta$ & т $(\mathrm{p})$ \\
\hline Ниво образовања & 0,081 & $2,305(0,021)$ \\
Приход домаћинства & 0,016 & $0,496(0,620)$ \\
Старост & $-0,086$ & $-2,831(0,005)$ \\
Величина насеља & 0,101 & $3,161(0,002)$ \\
\hline
\end{tabular}

Према моделу, постматеријалисти су заступљенији у млађој популацији са вишим нивоом образовања и у већим градовима. Резултати Павловићевог истраживања показују статистички значајан утицај свих обухваћених фактора: узраст, приход, образовање и величина насеља, при чему је најснажнији ефекат узраста и најслабији ефекат прихода. Треба приметити да Инглхарт (1977; Inglehart \& Abramson, 1999) сматра да је утицај висине прихода увек слабији од утицаја образовања и класе, јер упућује на тренутну материјалну ситуацију, док образовање и класа одражавају материјалну ситуацију у детињству. Како образовање делимично изражава материјалну ситуацију током формативних година, позитиван ефекат је у складу са

\footnotetext{
${ }^{2}$ Родне разлике у склоности постматеријализму нису интерпретиране у оквиру теорије нити емпиријски доследне; анализа је потврдила одсуство значајне повезаности са полом испитаника $\left(\chi^{2}=3,059, \mathrm{p}=0,217\right)$.
} 
Инглхартовом теоријом. Критичари наглашавају утицај образовања као механизма преношења демократских и либералних вредности (Dutch \& Taylor, 1993), док Инглхарт указује на вишеструкост чинилаца који доводе до снажног ефекта образовања, истичући да је образовање, између осталог, показатељ породичног социокултурног статуса током формативних година (Inglehart, 1977). Критика такође обухвата указивање на већи значај тренутног материјалног статуса у односу на ситуацију током формативних година, те одсуство значајног утицаја висине тренутног прихода у спроведеној анализи потврђују теорију модернизације, насупрот критици.

Значајан утицај старости је у складу са Инглхартовом теоријом, поготово узевши у обзир тренд раста заступљености постматеријалиста у млађим старосним категоријама. Треба напоменути да дати налаз ипак не искључује могућност да је ова правилност резултат ефекта животног циклуса, према коме је очекивана постматеријалистичка позиција у млађим категоријама становништва због својеврсног идеализма младости, који је у каснијим фазама живота модификован у контексту суочавања са проблемима који су у вези са материјалном ситуацијом, у пословној и породичној сфери. Дистрибуција вредности према старосним категоријама за 2001, 2005. и 2008. годину показује очекивани тренд веће заступљености постматеријалиста у млађим генерацијама (Табела 3), са наглашенијим порастом постматеријалиста и мешовитог типа у оквиру старосне групе од 55 до 64 година (рођени у периоду 1944-1953. године), који затим у следећој генерацији опада, али остаје виши него у најстаријој категорији становништва.

Утицај величине насеља Инглхарт не разматра директно, али примећује да тип насеља може бити од утицаја, јер је очекивано да сеоско становништво чешће посећује цркве, има ниже приходе и мање је изложено космополитским комуникационим каналима од остатка популације (Inglehart, 1977, стр. 89). Значајан утицај урбанизације, као и његова усаглашеност са теоријом модернизације, истакнути су и у оквиру критике хипотезе социјализације (Dutch \& Taylor, 1993, стр. 756). Дакле, иако величина насеља није кључни фактор у Инглхартовом моделу, може се приметити да је у складу са општим претпоставкама теорије; поред тога, присутна је значајна повезаност између прихода и величине града $(\rho=0,265, \mathrm{p}=0,000)$, која је у складу са интерпретацијом аутора. 
Табела 3. Дистрибуичија (пост)материјалиста у старосним категоријама

\begin{tabular}{|c|c|c|c|c|}
\hline & $\begin{array}{c}\text { Материјалистички } \\
\text { тип }\end{array}$ & $\begin{array}{l}\text { Мешовити } \\
\text { тип }\end{array}$ & $\begin{array}{c}\text { Постматеријалистички } \\
\text { тип }\end{array}$ & $\sum$ \\
\hline \multicolumn{5}{|c|}{ 2001. година } \\
\hline $15-24$ & $\begin{array}{r}42,3 \% \\
52\end{array}$ & $\begin{array}{r}51,2 \% \\
63\end{array}$ & $\begin{array}{r}6,5 \% \\
8\end{array}$ & $\begin{array}{r}100 \% \\
123\end{array}$ \\
\hline $25-34$ & $\begin{array}{r}39,8 \% \\
78\end{array}$ & $\begin{array}{r}52 \% \\
102\end{array}$ & $\begin{array}{r}8,2 \% \\
16\end{array}$ & $\begin{array}{r}100 \% \\
196\end{array}$ \\
\hline $35-44$ & $\begin{array}{r}41,1 \% \\
95\end{array}$ & $\begin{array}{r}51,1 \% \\
118\end{array}$ & $\begin{array}{r}7,8 \% \\
18\end{array}$ & $\begin{array}{r}100 \% \\
231\end{array}$ \\
\hline $45-54$ & $\begin{array}{r}49,2 \% \\
125\end{array}$ & $\begin{array}{r}44,1 \% \\
112\end{array}$ & $\begin{array}{r}6,7 \% \\
17\end{array}$ & $\begin{array}{r}100 \% \\
254\end{array}$ \\
\hline $55-64$ & $\begin{array}{r}52,5 \% \\
93\end{array}$ & $\begin{array}{r}42,4 \% \\
75\end{array}$ & $\begin{array}{r}5,1 \% \\
9\end{array}$ & $\begin{array}{r}100 \% \\
177\end{array}$ \\
\hline $65+$ & $\begin{array}{r}67,7 \% \\
130\end{array}$ & $\begin{array}{r}30,7 \% \\
59\end{array}$ & $\begin{array}{r}1,6 \% \\
3\end{array}$ & $\begin{array}{r}100 \% \\
192\end{array}$ \\
\hline \multicolumn{5}{|c|}{ 2005. година } \\
\hline $15-24$ & $\begin{array}{r}44,6 \% \\
50\end{array}$ & $\begin{array}{r}50 \% \\
56\end{array}$ & $\begin{array}{r}5,4 \% \\
6\end{array}$ & $\begin{array}{r}100 \% \\
112\end{array}$ \\
\hline $25-34$ & $\begin{array}{r}49,8 \% \\
107\end{array}$ & $\begin{array}{r}44,7 \% \\
96\end{array}$ & $\begin{array}{r}5,6 \% \\
12\end{array}$ & $\begin{array}{r}100 \% \\
215\end{array}$ \\
\hline $35-44$ & $\begin{array}{r}51,6 \% \\
97\end{array}$ & $\begin{array}{r}44,7 \% \\
84\end{array}$ & $\begin{array}{r}3,7 \% \\
7\end{array}$ & $\begin{array}{r}100 \% \\
188\end{array}$ \\
\hline $45-54$ & $\begin{array}{r}53,6 \% \\
105\end{array}$ & $\begin{array}{r}42,3 \% \\
83\end{array}$ & $\begin{array}{r}4,1 \% \\
8\end{array}$ & $\begin{array}{r}100 \% \\
196\end{array}$ \\
\hline $55-64$ & $\begin{array}{r}44,8 \% \\
60\end{array}$ & $\begin{array}{r}52,2 \% \\
70\end{array}$ & $\begin{array}{r}3 \% \\
4\end{array}$ & $\begin{array}{r}100 \% \\
134\end{array}$ \\
\hline $65+$ & $\begin{array}{r}67,1 \% \\
57\end{array}$ & $\begin{array}{r}30,6 \% \\
26\end{array}$ & $\begin{array}{r}2,4 \% \\
2\end{array}$ & $\begin{array}{r}100 \% \\
85\end{array}$ \\
\hline \multicolumn{5}{|c|}{ 2008. година } \\
\hline $15-24$ & $\begin{array}{r}33,6 \% \\
51\end{array}$ & $\begin{array}{r}57,9 \% \\
88\end{array}$ & $\begin{array}{r}8,6 \% \\
13\end{array}$ & $\begin{array}{r}100,0 \% \\
152\end{array}$ \\
\hline $25-34$ & $\begin{array}{r}39,9 \% \\
114\end{array}$ & $\begin{array}{r}54,9 \% \\
157\end{array}$ & $\begin{array}{r}5,2 \% \\
15\end{array}$ & $\begin{array}{r}100,0 \% \\
286\end{array}$ \\
\hline $35-44$ & $\begin{array}{r}43,0 \% \\
110\end{array}$ & $\begin{array}{r}52,3 \% \\
134\end{array}$ & $\begin{array}{r}4,7 \% \\
12\end{array}$ & $\begin{array}{r}100,0 \% \\
256\end{array}$ \\
\hline $45-54$ & $\begin{array}{r}45,7 \% \\
126\end{array}$ & $\begin{array}{r}48,9 \% \\
135\end{array}$ & $\begin{array}{r}5,4 \% \\
15\end{array}$ & $\begin{array}{r}100,0 \% \\
276\end{array}$ \\
\hline $55-64$ & $\begin{array}{r}40,6 \% \\
91\end{array}$ & $\begin{array}{r}50,9 \% \\
114\end{array}$ & $\begin{array}{r}8,5 \% \\
19\end{array}$ & $\begin{array}{r}100,0 \% \\
224\end{array}$ \\
\hline $65+$ & $\begin{array}{r}52,7 \% \\
129\end{array}$ & $\begin{array}{r}43,3 \% \\
106\end{array}$ & $\begin{array}{r}4,1 \% \\
10\end{array}$ & $\begin{array}{r}100,0 \% \\
245\end{array}$ \\
\hline
\end{tabular}


Индекс постматеријализма повезан је са одређеним продемократским схватањима и понашањем у Србији: постматеријалисти чешће потписују петиције ( $\rho=-0,097, p=0,000)$, учествују у демонстрацијама $(\rho=-0,118, \mathrm{p}=0,000)$ и бојкотима $(\rho=-0,156, \mathrm{p}=0,000)$, чешће се информишу о политици путем медија $(\rho=-0,099, \mathrm{p}=$ $0,000)$, дискутују о политици са пријатељима $(\rho=-0,066, p=0,000)$ и склонији су уверењу да је демократија најбољи политички систем ( $\rho$ $=-0,082, \mathrm{p}=0,003)$. Са друге стране, материјалисти чешће сматрају да демократија узрокује лоше економско стање $(\rho=0,082, \mathrm{p}=0,004)$ и не може да одржи ред $(\rho=0,116, p=0,000)$.

\section{ЗАКЉУЧАК}

Покушај објашњења ових промена у оквиру теорије модернизације Роналда Инглхарта пружа значајан допринос студијама вредности, а уз то инспирише и бројна разматрања и критике модела у његовој примени на националном нивоу. Поред значајних доприноса ове теорије, остају отворена питања димензионалности модела вредности и хипотезе социјализације, међутим, битно је напоменути да се на ова питања може само делимично одговорити на основу емпиријских резултата ограниченог просторног и временског обухата, те да је неопходна дискусија теоријских поставки уз разматрање алтернативних теоријских модела. Упркос евентуалним слабостима дате теорије, евидентан је њен објашњавалачки потенцијал, пре свега кроз мапирање вредности на глобалном нивоу.

Анализа података из Републике Србије указује на већу заступљеност постматеријалиста у млађим генерацијама него у старијим генерацијама, што је у складу са наведеном теоријом, али и са потенцијалним дејством ефекта животног циклуса. Регресиона анализа је на подацима из 2008. године показала да су значајни ефекти старости, нивоа образовања и величине града на заступљеност постматеријализма, при чему је постматеријализам присутнији код млађег, високообразованог становништва из већих градова. Утицај висине прихода није значајан у моделу, што је у складу са Инглхартовом теоријом, према којој материјални статус значајно утиче на формирање вредности, али само током формативних година, те касније промене у приходима током живота нису релевантне за драстичне промене у (пост)материјалистичким вредностима. Компарација са претходним истраживањима указује на доследност резултата позиције Србије као земље материјалистичких вредности. Постматеријализам је значајан и као елемент ширег концепта, димензије самоекспресије, која се показала као значајан елемент у успостављању и одржању демократије. Низак удео постматеријалиста и превладавање мешовитог типа у популацији указује на проблематичан ниво политичке 
културе као препреке остварењу суштинске демократије, насупрот формалној. Иако је присутан тренд пораста постматеријалиста у млађим генерацијама, реч је о малим и спорим променама, које, заједно са карактеристикама осталих елемената димензија вредности, смештају Србију на незавидну позицију на глобалној мапи вредности.

\section{ЛИТЕРАТУРА}

Abramson, P. R. \& Inglehart, R. (1992). Generational Replacement and Value Change in Eight West European Societies. British Journal of Political Science, 22 (2), 183-228.

Bean, C. \& Papadakis, E. (1994). Polarized priorities or flexible alternatives? Dimensionality in Inglehart`s materialism-postmaterialism scale. International Journal of Public Opinion Research, 6 (3), 264-288.

Braithwaite, V., Makkai, T.\& Pittelekow, Y. (1996). Inglehart's MaterialismPostmaterialism Concept: Clarifying the DimensionalityDebate Through Rokeach'sModel. Journal of Applied Social Psychology, 26 (17) 1536-1555.DOI: 10.1111/j.1559-1816.1996.tb00085.x

Brooks, C. \& Manza, J. (1994). Do Changing Values Explain the New Politics? A Critical Assessment of the Postmaterialist Thesis. The Sociological Quarterly, 35 (4), 541-570.

Davis, D. W. (2000). Individual Level Examination ofPostmaterialism in the U.S.:Political Tolerance, RacialAttitudes, Environmentalism, and Participatory Norms. Political Research Quarterly, 53 (3), 455-475.

Davis, D. W. \& Davenport, C. (1999). Assessing the Validity of the Postmaterialism Index. American Political Science Association, 93 (3), 649-664. DOI: $10.2307 / 2585580$

Davis, D. W., Dowley, K. M.\& Silver, B. D. (1999). Postmaterialism in World Societies: Is It Really a Value Dimension? American Journal of Political Science, 43 (3), 935-962.

De Graaf, N. D. \&Evans, G. (1996). Why are theyoung more postmaterialist? A Cross-National Analysis of Individual and Contextual Influences on Postmaterial Values. Comparative Political Studies, 28 (4), 608-635.

Dutch, R. M. \& Taylor, M. A. (1993). Postmaterialism and the Economic Condition. American Journal of Political Science, 37 (3), 747-779.

Гавриловић, Д. (2013). Доба употребе: религија и морал у савременој Србији. [The Age of Use: Morality and Religion in Contemporary Serbia] Ниш: Филозофски факултет у Нишу. [Nis: Faculty of Philosophy in Nis]

Giacalone, R. A.\& Jurkiewicz, C. L. (2004). The interaction of materialist and postmaterialist values in predicting dimensions of personal and social identity. Human Relations, 57 (11), 1379-1405. DOI: 10.1177/0018726704049414

Inglehart, R. (2007). Mapping Global Values. In: Esmer, Y. \& Pettersson, T. (eds.). Measuring and Mapping Cultures: 25 Years of Comparative Value Surveys. Boston: Brill, 11-33.

Inglehart, R. \& Welzel, C. (2005). Liberalism, Postmaterialism, and theGrowth of Freedom, International Review of Sociology, 15 (1), 81-108, DOI: 10.1080/ 03906700500038579

Inglehart, R. \& Baker, W. E. (2000). Modernization, cultural change and the persistence of traditional vaules, American Sociological Review, 65, 19-51. 
Inglehart, R. (2000). Globalization and Postmodern Values.The Washington Quarterly, 23 (1), 215-228.

Inglehart, R. \& Abramson, P. R. (1999). Measuring Postmaterialism. The American Political Science Review, 93 (3),665-677.

Inglehart, R. (1997). Modernization, postmodernization and changing perceptions of risk, International Review of Sociology: Revue Internationale de Sociologie, 7 (3), 449-459, DOI: 10.1080/03906701.1997.9971250

Inglhart, R. (1977). The Silent Revolution: Changing Values and Political Styles Among Western Publics. Princeton, New Jersey: Princeton University Press.

Marks, G. N. (1997). The Formation of Materialist and Postmaterialist Values. Social Science Research, 26, 52-68.

Пантић, Д. (1990). Промене вредносних оријентаиија младих у Србији. [Changes in value orientations of young people in Serbia] Београд: Институт друштвених наука [Belgrade: Institute of Social Sciences]

Pavlović, Z. (2009). Is there a sociodemographic model of acceptance of postmaterialist values? The case of Serbia. Sociologija, 51(2), 177-188.

Павловић, 3. (2006). Вредности у Србији у другом добу модернизма. [Values In Serbia in Second Age of Modernity] Сочиолошки преглед [Sociological Review], 40(2), 247-262.

Trump, T. M. (1991). Value formation and postmaterialsim: Inglehart's theory of value change reconsidered. Comparative Political Studies, 24(3), 365-390.

\section{POSTMATERIALISM IN SERBIA}

Nina Pavlović

University of Niš, Faculty of Philosophy, Department of Sociology, Niš, Serbia

\section{Summary}

According to the theory of modernization of Ronald Inglhart, with the transition from a traditional to a modern society there are changes in value orientations along two dimensions: a) traditional/secular-rational values and b) survival/selfexpression values. These changes are explained on the basis of the hypothesis of scarcity and the hypothesis of socialization. In the revised modernization theory, author emphasizes probabilistic character of this process, affirming the influence of cultural identities and the path of society's development.

Postmaterialism is a key element of the dimension of survival/selfexpression values and it is operationalized by the index that measures the preferences of respondents between the offered state goals: maintaining order, suppressing price growth, increasing citizen participation in decision-making and protecting freedom of speech. According to hypotheses of scarcity and socialization, the postmaterial values are predominant in younger age groups in modern societies. One of the significant contributions of the index of postmaterialism is reflected in the possibilities of predicting the potential of political culture, given the established high correlation of self-expression values with the establishment of democratic institutions.

The results of the previous research indicate the prevailance of materialistic values in Serbia. This paper analyzes data from the European and World Values Studies from 2001, 2005 and 2008. Materialistic values prevail in 2001 and 2005, and the mixed type in 2008 while post-materialist values are the least frequent in all three years. A regression model is 
applied to the data from 2008 for examining significant sociodemographic factors affecting postmaterialism. The regression model is significant $(\mathrm{F}=10.960, \mathrm{p}=0.000)$ and explains $3.4 \%$ variance. The strongest impact is the size of the settlement, while the influence of age and level of education is almost equal in intensity. A significant impact of age is consistent with Inglhart's theory, especially considering the growth trend of postmaterials in younger age categories, but does not exclude the impact of the life cycle. The effect of the size of settlements and education is partly explained in the framework of the revised theory of modernization: the size of the settlement is related to the effects of urbanization in the form of exposure to differences, and the importance of education is explained by the indirect influence of the material situation.

According to the model, postmaterialists are more frequent in the younger population with higher education levels and in larger cities. The connection between postmaterialism and some pro-democracy activities and beliefs was found. In addition to the open questions of the structure of the index of postmaterialism and national specificities, the significance and contribution of Inglhart's theory to value studies was pointed out. 